\title{
A Preliminary Study on the Nature of Game Concept
}

\author{
Husheng Pan ${ }^{1}$, Chenjie Guo² and Yuehua Chen ${ }^{3, a}$ \\ ${ }^{1}$ Mechatronics engineering, Harbin Institute of Technology, Harbin 150000, China \\ ${ }^{2}$ School of mechanical engineering, Shandong University, Jinan 250100, China \\ ${ }^{3}$ List all distinct addresses in the same way \\ acyh@hit.edu.cn
}

Keywords: game; concept; nature

\begin{abstract}
Since the birth of humans, the game has become a common phenomenon of humans and a basic part of life. Especially in human childhood, the two are inseparable, just like body and shadow. But what exactly is a game? At present, there are many statements on the nature of game concept in domestic and foreign academic circles, but they haven't formed a common and unified understanding. In this paper, we attempt to interpret the nature of game concept from two perspectives, i.e., the origin and etymology of Chinese and foreign games. We consider that the gift of freedom, the spirit of competition and the behavior of play, etc. can be regarded as basic semantic elements of "the nature of game". But from a broader scope, as long as people treat life with a game attitude, life is actually a game.
\end{abstract}

\section{A Brief Introduction to the Origins of Chinese and Foreign Games}

(I) The Genesis of Western Games

As early as the end of 12th Century, the blind Greek poet, Homer, documented in Homeric Hymns that Spartan children had hobbyhorses, swings, roll rings and other toys to play with in their leisure time on the Greek Peninsula. People also used these tools to spread and practice knowledge and skills for their descendant's life and labor [1]. More than 1000 years later, these games evolved into a large-scale Olympic sports event in Greece. During this period, competitions had been well-established. There was grappling, racing, archery, horse riding, discus throw, wrestling and boxing, etc., which laid a foundation for ancient Greek games. The influence was far-reaching. Now it has developed into the world's largest sports game for all mankind.

(II) The Genesis of Chinese Games

In the east, Chinese games also have a long history and wide variety. Chinese archaeologists unearthed plenty of stone balls more than 1 million years ago in Gongzhuling, Lantian, Shaanxi Province. The ball is widely acknowledged as one of the most common sports of human beings. They have been deeply favored by people for a long time. It is said that a ball game called “蹴鞠(Cuju)” invented by the Yellow Emperor, enjoyed enduring popularity and prevailed in two Song dynasties, as evidenced in a poem written by Lu You, “少年骑马入咸阳, 鹘似身轻蝶似狂; 蹴鞢场边万人 看, 秋千旗下一春忙” (A young man rides a horse to Xianyang. He is robust and wanders around. He watches football with tens of thousands of people on the football field and watches swing matches on the swing field). From this, we can see how popular and beloved the ball game was at that time. Apart from this, there was a dazzling array of folk acrobatics, too. By the Shichahai Lake, a modern person, Ma Guojun browsed ancient books and authored An Encyclopedia of Traditional Chinese Games. There were 13 categories of games in Chinese traditions, i.e., ancient wrestling, drinkers' wager games, chesses, shooting and balls, etc., which can be subdivided into more than 100 small games. They revealed the rich game life of ancient Chinese to the world[2]. 


\section{The Etymology of Game}

We searched for the linguistic and etymological roots of "game", in the hope of exploring the origin of games.

(I) An Etymological Analysis of Game in Ancient Chinese

In 1956, Resolution on Publishing a Chinese Simplification Scheme was unveiled in China for the first time. From this scheme, we know that the origin of a common Chinese character “游” today was “斿”. Originally, it was composed of “之” and “斿”. In connotation, the original definite meanings of “之” and “斿” were added to “游”. According to The Ritual of Zhou, “游” was abbreviated as “斿” and extended to designate all floating or drooping things. The Book of Songs: Long Hair also said, "They lift a flag for dukes or princes under the emperor". In the period of Warring States, Wang Yi wrote about flags in Nine Songs and annotated that偃塞 (yanjian) was a dancing posture. After leafing through the oldest dictionary in China, Shuowen Jiezi ("Explaining Graphs and Analyzing Characters”), we found that it defined ““斿” as “a flying streamer on a flag. Jingqi (旅旗) was a generic term of banners and flags. They were bent and drooped, hence the name “斿”. The bent and drooped posture looked like floating, hence the name “游”. Also, it was said that the ancient character “斿” looked like a streamer on a flag and resembled the shape of 斿. From here, we can see that “游” was first used as a generic term for all things that drooped or floated. The original meaning was the appearance and "intoxicated" state of a dancer. Later in the Eastern Han Dynasty, Xu Shen defined “游” in Shuowen Jiezi, as "the flow of flags, which is just like the flow of water, hence the name 'flow'. 游 derives from 斿 and sounds like flowing water. [3]” The original meaning of “游” was a drooping streamer or tassel on a flag. In Zuo Tradition: 12th Year of King Huan of Zhou, the word “游” in “鎜厉游缨, 昭其数也” had the same meaning. All of them extended the state of flowing water and free wind to refer to a kind of carefree, leisurely and unrestrained "freedom".

As a verb, 斿 is interchangeable with “遊” and can refer to travel, tour or visit, etc. Just as in “说 冕牟之斿是” in Mou Shi , “斿” is extended to the meaning of travel or divertissement and commonly written as “游”. Other examples include “膳饮从于遊” in the Book of Rites: Royal Regulations and “噬肯来遊” in the Book of Songs: Odes of Tang: A Lonely Birchleaf Pear Tree.

戏 (play) was originally written as “戯”. It is an associative term and means that someone wears a tiger mask and dances with a dagger-axe in his hand, during a sacrifice or feast. Discourses of the States: Discourses of Jin, Chapter 9 says “少室周为赵简子之右, 闻牛谈有力, 请与之戏, 弗 胜, 致右焉(Shao Shizhou is the right escort of Zhao Jianzi. He hears that Niu Tan has great physical strength, so he challenges him to have a contest. But he is defeated, so he relinquishes his post in favor of Niu Tan).” Wei Zhao annotated that, “戏means wrestling.” For another example, in Shuowen Jiezim, “戯 is a special unit of armed forces. There is a saying that 戯 is a weapon and uses ‘戈” as its component”. In literary works, such as “剧孟行大类朱家, 而好博, 多少年之戏” in Shiji, Ranked Biographies of Knight-errants and “宣德间，宫中尚促织之戏，岁征民间” in Strange Stories from a Chinese Studio: Cricket, “戏” has the meaning of game and play. While in “云烟古寺闻僧梵, 灯 火长桥见戏场” in Outing written by Lu You, “戏” means the performance of musical dramas.

The combination between “游” and “戏” originated from “言堂满堂者, 非特谓游戏饮食之言 也, 必谓大物也。” by Han Feizi, Here, the meanings of “游” and “戏” are basically the same as the modern term “游戏” and mainly refer to frolicking, play and entertainment.

It is thus clear that competition, game, performance, drama and play etc. can be derivative semantic elements of the word "game", besides freedom. In contemporary and modern times, more specific meanings of the word "game" have been generalized on this basis. For example, in Cihai, "game" is defined as "one of the most important means of sports, a kind of cultural entertainment, including intellectual games (e.g. chess, block and crossword) and activity games (e.g. hide and seek, carry and relay) and competitive games (e.g. football and table tennis). Games usually have rules and play a certain role in developing intelligence and physical strength [4]" The entries of "game" in 
Modern Chinese Dictionary can be divided into three categories: I. amusement, play and entertainment; II. Frivolous or unserious banters; III. Recreational or related activities [5].

(II) An Etymological Analysis of Game in the West

There is a unique way to express children's games in Greek, that is, to add a suffix "inda” to various words, such as, sphairinda (Greek children's ball game), helkustinda (tug-of-war game) and streptinda (throwing game). Inda is not derived from other words. In language, it doesn't have any grammatical or morphological changes. It reveals Greeks' understanding of the unique status of games. In Sanskrit, there are at least four roots to express Game Concept. The most common is Kridati, which refers to games for animals, children and adults. Just like the work "game" in Germanic languages, it is used to refer to the movement of wind and waves, as well as jumping, leaping or common dances. It is not necessarily related to a particular game. The second is divyati, which mainly refers to gambling or dicing, as well as games in the sense of play, frolicking or banter. The third is las (derived from vilasa), which means shining, appearing suddenly, moving back and forth, playing with something or "chasing”. Different from Sanskrit which uses many roots to express Game Concept, Latin only has a word to cover the general concept of game, i.e., ludus, which derived from ludere. In etymology, the former can be used to refer to the jumping of a fish, the fluttering of a bird and the splashing of water, etc., while the latter includes children's games, entertainments, competitions, performances in religious rites and dramas and all kinds of speculative games. But ludus, the general term that refers to games, doesn't enter the Latin languages and have almost no influence on these languages. Later, after being replaced by a derivative jocus, it acquires the meaning of fun and frolicking. In this manner, there are jeu and jouer in French, gioco and giocare in Italian, juego and jugar in Spanish and jogo and jogar in Portuguese [6].

In modern times, the word "game" is endowed with more specific meanings. According to The New German-Chinese Dictionary (revision), in German, the noun form of game is spiel. It has the following meanings: (1) a play, entertainment or recreation; (2) gambling; (3) an entertaining game;(4) a (sports) game;(5) a round of (billiard, card game or tennis, etc.); (6) a play or drama; (7) (irregular and aimless) jumping, flashing or floating; (8) frolicking or children's play;(9) a set. While in German, the verb form of game is spielen, which has the same root as speil. The verb spielen has the following meanings: (1) to play or have fun; (2) to gamble or bet;(3) the same competition or sports event: (4) to play or play music;(5) to perform or act; (6) (a story) to happen;(7) to flap or dance; (8) to shine or flicker;(9) to tease, joke, not take it seriously or flirt [7].

\section{The Nature of Game Concept}

By teasing out the genesis process of games in various Chinese and western of linguistics and etymologies, we find that foreign countries treat the word "game" mainly by interpreting it in a realistic category, at a rational level. Games are objective recreation activities about plays, competitions and dramas, etc. While for Chinese, a "game" not only has the above meaning, but focuses more on a carefree, free and cheerful realm of spirit and further develops into a subjective experience about the nature of men and "the game of life".

However, what exactly is a game? Plato clearly described the relationship between rites, dances, music and other general concepts in life with games in his work, Laws, [8] "God is the natural and worthy object of our most serious and blessed endeavors, for man, as I said before, is made to be the plaything of God, and this, truly considered, is the best of him; wherefore also every man and woman should walk seriously, and pass life in the noblest of pastimes, and be of another mind from what they are at present...And what is the right way of living? Are we to live in sports always? If so, in what kind of sports? We ought to live sacrificing, and singing, and dancing, and then a man will be able to propitiate the Gods. [8] And music is a game, too, "to men the very gods, who were given, as we said, to be our fellows in the dance, have granted the pleasurable perception of rhythm and harmony.[9]"

So for the nature of "game", we can perceive in this way: the gift of freedom, the spirit of competition and the behavior of play, etc. can be regarded as basic semantic elements of "the nature of game”. But from a broader scope, apart from what Plato illustrated, all basic categories in life, such 
as competitions, rites, dances and music, etc. are all games. As long as people treat life with a game attitude, further speaking, life is actually a game.

\section{Acknowledgements}

Fund project: This paper is the national social science fund project 《serious game spread socialist core values of the design strategy and mode of operation》 (16BXW004) stage results.

\section{References}

[1]Homer, Bernard Knox Robert Fagles. The Odyssey [M]. English: Penguin Classics, 2014: 409-581.

[2] Ma Guojun and Ma Shuyun. An Encyclopedia of Traditional Chinese Games [M]. Beijing: Rural Reading Press, November 1990, 1st Edition.

[3] [Han Dynasty] Xu Shen, trans. Duan Yucai, Shuowen Jiezi [M]. Shanghai: Shanghai Chinese Classics Publishing House, October 1981, 1st Edition, pp. 559-563.

[4] Shu Xincheng, Cihai [M]. Shanghai: Shanghai Lexicographical Publishing House, April 2010, 1st Edition.

[5] See Modern Chinese Dictionary [M]. Shanghai: Publishing House of the Unabridged Chinese Dictionary, 2002.

[6] [Netherlands], Johan Huizinga, trans. Cheng Qiong, Man the Player [M]. Guizhou, Guizhou People’s Publishing House, August 2007, 1st Edition: pp.26-42.

[7] Pan Zaiping, The New German-Chinese Dictionary [M]. Shanghai: Shanghai Translation Publishing House, 2000 Edition.

[8]Johann .Huizinga. Homo Ludens: A Study of the Play Element in Culture [M], oston: Beacon Press, 1955: p. 212.

[9][Ancient Greece] Plato, The Collected Dialogues of Plato [M]. Beijing: People's Literature Publishing House, 1963 Edition: p.301. 